\title{
Physicochemical characterization and antimicrobial properties of Mahamanjishthadi kadha: An Ayurvedic formulation
}

Kapil Thakur**, P. Mini Mol, Madhuree Gawhankar**, Himanshu Gupta, Priyanka Patil**, Shabina Salmani and Mansee Thakur MGM School of Biomedical Sciences, MGMIHS, Kamothe-410206, Navi Mumbai, Maharashtra, India

*Shree Dhootapapeshwar Limited, Panvel-410206, Navi Mumbai, Maharashtra, India

**Shree Dhootapapeshwar Ayurvedic Research Foundation, Panvel-410206, Maharashtra, India

\section{Article Info}

Article history

Received 4 April 2020

Revised 27 May 2020

Accepted 29 May 2020

Published online 30 June 2020

Keywords

HPTLC

Antimicrobial

Mahamanjisthadi kadha

Skin infections

Lupeol

Gallic acid

Ellagic acid

\begin{abstract}
Skin infections are common throughout the world. With high infectivity amongst skin pathogens, approximately 300 million people are affected worldwide. The increasing rate of failure of chemotherapeutics and antibiotic resistance exhibited by pathogenic microbial infectious agents, has increased the use of Ayurvedic medicines. This study aims to standardize an Ayurvedic formulation, Mahamanjisthadi kadha and to evaluate its antimicrobial properties against skin infection, causing pathogens. Physicochemical analysis such as organoleptic tests, pH, alcohol content, Brix and Specific gravity was done. Phytochemical screening was performed for various bioactive compounds. Heavy metals, aflatoxins and microbial load were checked for contaminants. Chromatographic analysis was performed to estimate lupeol, ellagic acid and gallic acid, using high performance thin layer chromatography (HPTLC). Antimicrobial activity was determined against five common pathogens causing skin infections, using well-diffusion method.

Organoleptic tests confirmed brown color and characteristic odor of self generated alcohol with bitter and astringent taste. Phytochemical screening showed the presence of alkaloids, steroids, triterpenoids, tannins, phenolic compounds, saponins and flavonoids. HPTLC analysis confirmed the presence of lupeol, ellagic acid and gallic acid. Heavy metals, aflatoxins and microbial load were found within the permissible limit. Antimicrobial study showed the formulation could inhibit growth of Staphylococcus aureus, Candida albicans, Pseudomonas aeruginosa, Staphylococcus epidermidis and Escherichia coli. The study presented has completely characterized the formulation will serve as reference to develop quality control profile of Mahamnjishtadi kadha and help in validating therapeutic efficacy of this formulation.
\end{abstract}

\section{Introduction}

The World Health Organization (WHO) reported that the $80 \%$ of the world's population depend on traditional medicine for their primary healthcare needs because of significant economic benefits in the development of indigenous medicines and in the use of medicinal plants for the cure of various diseases (Taid et al., 2014). Usage of herbal and natural products has seen an upsurge across the globe (Vaidya and Devasagaya, 2007). This increased interest in botanical drugs has necessitated the need of standardization of quality and manufacturing. In order to ensure consistency in manufacturing process, the drugs need to be characterized scientifically. Standardization is a process of making a drug conforms to a type or standards in order to deliver a safe, efficacious and quality product. It is an important process in defining a quality program for production of herbal drug (Bhope et al., 2011).

Corresponding author: Dr. Kapil Thakur

Shree Dhootapapeshwar Limited, Panvel-410206, Navi Mumbai, Maharashtra, India

E-mail: ksthakur123@gmail.com; kst@sdlindia.com

Tel.: +91-9867199737

Copyright (C) 2020 Ukaaz Publications. All rights reserved.

Email: ukaaz@yahoo.com; Website: www.ukaazpublications.com
The primary focus of Ayurvedic medicine is to prevent illness, promote good health. It has been known since ancient in Ayurveda that a connection exists between the skin and mind. The negative impact on mind leads to stress which in turn directly or indirectly plays a major role in the manifestation and aggravation of skin diseases (Singh et al., 2014).

Human skin, the outermost layer of the body is known to act as the first line of defense. Human skin is constituted of three specialized layers, i.e., epidermis, dermis and hypodermis whereby each layer has their defined role in the function of the skin. Skin acts as an interface of body with the environment, has a vital role in protecting the body against pathogens (Proksch et al., 2008) and acts as an barrier for water loss from body (Kathi and Madison, 2003). Besides this, skin helps in body temperature regulation, vit D synthesis through UV sun rays, absorption of oxygen and plays significant role in drug absorption (Grice et al., 2009).

However, our first line of defense is prone to various bacterial, fungal, viral and parasitic infections and all age groups, covering the neonate to the elderly get affected by skin ailments in number of ways (Marks and Miller, 2006). Approximately 300 million people 
are being infected with various types of skin infection every year (Rani et al., 2015). There are many types of skin infections such as rashes, pigmentation, burn, wound, cellulites, impetigo, acnevulgaris, psoriasis, and folliculitis. The severity of skin infection ranges from minor superficial lesions to major invasive, fulminate tumor and cancers (DiNubile and Lipsky, 2004).

Bacterial skin infections are mainly caused by E. coli, Staphylococcus aureus, Staphylococcus epidermidis, Streptococcus pyogenes, and Pseudomonas aeruginosa. While major fungal infections of skin are due to C. albicans and C. neoformans (Kohen, 1999). Staphylococci causes wound infections, furuncles, carbuncles, impetigo and abscesses. Escherichia coli is part of the physiological intestinal flora but outside intestine, they may cause wound infections. P. aeruginosa is the most common pathogen known to risk skin infections in burn patients. C. albicans and C. krusei presence on skin and mucous membranes is known to cause impetigo and candidacies in diabetic's patients and immune deficient people (Chanda et al., 2009).

Modern medicine provides various treatments for skin infections, but therapy should be in line with the type and severity of skin infections. Mostly, the treatment includes prolonged use of topical creams, lotions, oral antibiotics and anti-inflammatory drugs. These medicines are known to provide effective management but these medications, are also known to show various side effects like burning sensation, erythema, skin dryness, scaling.

Besides the side effects, bacterial resistance is also noticeable. Some antibiotics like vancomycin, linezolid and silver sulfadiazine were found resistant to Staphylococcus aureus and Streptococcus pyogenes (Prateek et al., 2016). Methicillin-resistant, S. aureus (MRSA) are in rising frequency and have showed resistance to vancomycin (Zinn et al., 2004). 9\% of the Candida species isolated were analysed and found to be resistant to fluconazole and itraconazole (Perea and Patterson, 2002).

Hence, the healthcare fraternity is looking for alternative treatment options for skin diseases and infections (Feldman et al., 2004). Plant based Ayurvedic drugs are having several advantages over synthetic drugs such as fewer side-effects, better patient tolerance, more acceptable due to a long history of traditional use. Besides this, Ayurvedic medicines have rational means for the understanding of many disorders and abnormalities that are not understood in other systems of medicine. So, various Ayurvedic medicines are being studied in depth, having indications for treatment of skin diseases ranging from itching to skin cancer (Tabassum and Hamdani, 2014).

Medicinal herbs play an important role in the wound healing process by encouraging blood clotting, fighting infections and accelerate the wound healing process (Maz'uma, 2018). Secondary metabolites (phytochemicals) present in plants, help in developing new antimicrobials compounds for various skin infectious diseases.

Various forms of Ayurvedic medicines such as Churna, Avaleha, Bhasmas, Asavas, Arishthas, Kadhas, Tailas are being used since ancient time to present era. Asavas, Arishtas and kadhas are important group of ayurvedic formulations used as medicines to treat various disorders in Ayurveda for over 3000 years (Singh et al., 2010).

Mahamanjisthadi kadha a classical Ayurvedic formulation, is prescribed by ayurvedic physicians for various skin ailments. It helps in improving colour and complexion of skin. It has been recommended in all types of skin disorders (Shrivastava, 1998).

The formulation contains more than 40 medicinal herbs which includes Manjishtha (Rubia), Sariva (Hemidesmus indicus Linn), Nimba (Azadirachta indica A. Juss.), Haridra (Curcuma longa Linn.), Khadir (Acacia catechu Linn. f.), Bibhitaki (Terminalia bellerica Gaertn.) Roxb.), Haritaki (Terminalia chebula (Gaertn.) Retz.) and Amalaki (Emblica officinalis Gaertn.), etc. A complete list of ingredients of the formulation is listed in Table 1. These medicinal herbs have good antimicrobial activity against skin infection causing pathogens (Alavijeh et al., 2012).

Ayurvedic medicines are widely accepted for its holistic approach to treat the disease naturally. Unfortunately standardization of Ayurvedic medicines have remained challenging due to multiple ingredients, varied chemical matrix present in herbal medicinal plants. Hence, Ayurvedic ingredients or its preparation are considered as active compound irrespective of whether its constituents are known to show therapeutic activity. This has been referred in the draft of the strategic plan for the regional traditional medicine of WHO (Bhope et al., 2011).

In quality control methods for medicinal plant materials, WHO has clearly specified for development of fingerprint profile for all botanical preparations (Alavijeh et al., 2012; WHO, 1998; WHO, 1992). Every drug should have complete information related to its organoleptic properties, physicochemical characteristics and phytoconstituents.

There is limited information of this Ayurvedic formulationMahamanjishthadi kadha with reference to phytochemical, physicochemical and antimicrobial profile. Hence, a standardization and characterization study was planned on this formulation to define complete quality profile and evaluate its antimicrobial effect on various skin related ailments. Antimicrobial activity was studied against E. coli, P. aeruginosa, S. aureus, S. epidermidis and Antifungal activity against C.albicans.

\section{Materials and Methods}

\subsection{Materials}

Three batches of Ayurvedic formulation, Mahamanjisthadi kadha (Batch I, Batch II and Batch III), formulated as per text reference Sharangadhar Samhita Madhyam Khanda 2/139-144 were procured from Shree Dhootapapeshwar limited stockist. The formulation contains more than 40 medicinal herbs which includes Sariva (Hemidesmus indicus Linn), Bibhitaki (Terminalia bellerica (Gaertn.) Roxb.), Haritaki (Terminalia chebula (Gaertn.) Retz.), Amalaki (Emblica officinalis Gaertn.), Manjishtha (Rubia cordifolia Linn), Nimba (Azadirachta indica A. Juss.), Haridra (Curcuma longa Linn.), Khadir (Acacia catechu Linn.), etc. A complete list of ingredients of the formulation is listed in Table 1. 
Table 1: Ingredients of Mahamanjishthadi kadha

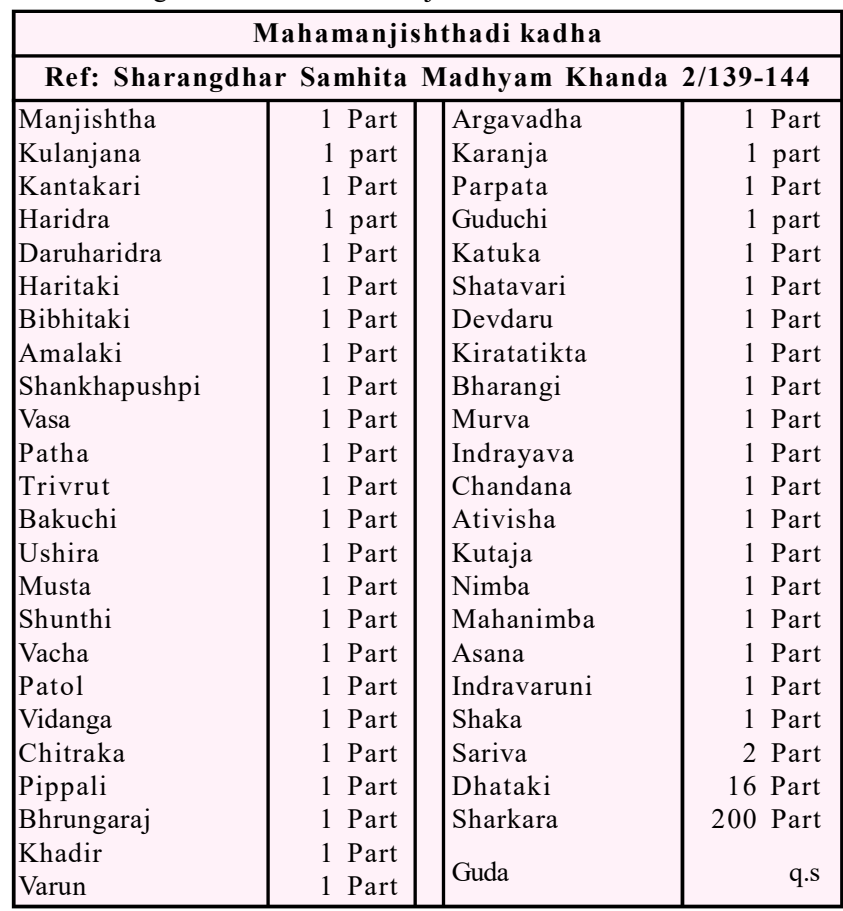

All chemicals and reagents (Toluene, Chloroform, Ethyl acetate, Acetic acid, Formic acid, Methanol, etc.) used for analysis, were of analytical reagent grade, purchased from Merck. The certified reference standards (CRS), such as lupeol of purity $99.0 \%$ (CAS No. 545-47-1), gallic acid of purity $98.50 \%$ (CAS No, 149-91-7) and ellagic acid of purity $99.80 \%$ (CAS No, 476-66-4) were procured from Natural Remedies Private Limited for HPTLC Analysis.

Mercury $(\mathrm{Hg})$ and multi element standard of lead $(\mathrm{Pb})$, cadmium (Cd), arsenic (As) were procured from Merck and Perkin Elmer, respectively. Aflatoxin Mix 4 (B1, B2, G1 and G2) analytical standard solution was purchased from Sigma-Aldrich.

Nutrient Broth, Nutrient Agar and microbial strains of Escherichia coli (ATCC 25922), Pseudomonas aeruginosa (ATCC 27853), Staphylococcus aureus (ATCC 6538), Staphylococcus epidermidis (ATCC 51625) and Candida albicans (ATCC 10231) were purchased from HiMedia Laboratories Private Limited.

\subsection{Methods}

\subsubsection{Organoleptic evaluation}

Organoleptic evaluations like colour, odour, and taste of the formulations were analyzed as preliminary quality check (Siddiqui, 1995).

\subsubsection{Physicochemical evaluation}

Different physicochemical parameters like $\mathrm{pH}$, Brix, Specific gravity and alcohol content were evaluated. The digital $\mathrm{pH}$ meter was used for the $\mathrm{pH}$ measurement after calibration with buffer solutions. Brix was determined using refractometer. Specific gravity and alcohol content was determined as per the method prescribed in The Ayurvedic Pharmacopoeia of India (API, 2008).

\subsubsection{Phytochemical screening}

Phytochemical screening was performed for the detection of various bioactive compounds such as alkaloids, steroids, triterpenoids, tannins, phenolic compounds, saponins, flavonoids, etc., from the aqueous extract of the formulation, using following standard chemical methods (Debiyi and Sofowora, 1978; Rupashree et al., 2008; Sofowora, 1993; Trease and Evans, 1989; Kokate et al., 2009; Khandelwal, 1995; Clarke, 1975; Raman, 2006; De, 2010; Nduche et al., 2018).

\subsubsection{Test for alkaloids}

Dragendorff's test: Aqueous extract of formulation was treated with Dragendorff's reagent and observed for reddish brown precipitate to confirm presence of alkaloids.

\subsubsection{Test for steroids and triterpenoids}

Salkowski test: Aqueous extract of formulation was treated with chloroform and few drops of concentrated sulfuric acid. Solution was observed for red color appearance at the lower layer to confirm the presence of steroids and formation of yellow colored lower layer to confirm the presence of triterpenoids.

\subsubsection{Test for tannins and phenolic compounds}

Alkaline reagent test: Aqueous extract of formulation was treated with sodium hydroxide solution and observed for yellow to red precipitate.

\subsubsection{Test for saponins}

Frothing test: The distilled water was added to aqueous extract of formulation and shaken vigorously for $5 \mathrm{~min}$. The solution was monitored for frothing effect to confirm the presence of saponins.

\subsubsection{Tests for flavonoids}

Alkaline reagent test: Aqueous extract of formulation was treated with few drops of sodium hydroxide solution and monitored for an intense yellow color which turns to colorless on addition of few drops of dilute acid.

\subsubsection{Quantification of phytochemicals by HPTLC}

Camag HPTLC instrument with sample applicator Linomat 5, Densitometer TLC scanner 4 and Wincat Software was used for quantification of phytochemicals by chromatographic analysis (HPLTC) of Mahamanjisthadi kadha. The precoated silica gel G60$\mathrm{F}_{254}$ aluminium sheets (E. Merck, Germany) $20 \times 10 \mathrm{~mm}$, thickness layer $0.2 \mathrm{~mm}$ were used as stationary phase. The solvent systems toluene: ethyl acetate $(10: 3) \mathrm{v} / \mathrm{v}$ for lupeol and chloroform: ethyl acetate: formic acid $(5: 4: 1.6) \mathrm{v} / \mathrm{v} / \mathrm{v}$ for gallic acid and ellagic acid was selected which gave good resolution. Twin trough chamber was used for development of HPTLC plates. Photo documentation cabinet fitted with high resolution camera was used for capturing images at different wavelengths. Densitometer TLC scanner 4 equipped with deuterium (D2) and tungsten (W) lamps were used to obtain spectra. The wavelengths of $600 \mathrm{~nm}, 290 \mathrm{~nm}$ and $278 \mathrm{~nm}$ were used for quantification of lupeol, gallic acid and ellagic acid, respectively in the formulation. The methods developed for quantification of lupeol, gallic acid and ellagic acid were validated as per ICH guidelines (ICH, 2005). 


\section{Method validation}

Method validation was performed as per standard ICH guidelines which included linearity, precision, accuracy, specificity, LOD and LOQ (ICH, 2005). Linearity of method was performed by plotting calibration curves for gallic acid, ellagic acid and lupeol. Precision was performed by estimating intraday and interday readings and $\%$ RSD relative standard deviation. Accuracy of analytical methods was expressed as \% recovery. This was estimated by adding known concentration of standard solution to pre-analyzed sample solution. Specificity of method was assessed by confirming the spectra and $\mathrm{Rf}$ value of sample matching with the reference standards of gallic acid, ellagic acid and lupeol. Limit of detection (LOD) and limit of quantification (LOQ) were estimated as per formula: $\mathrm{LOD}=3.3 \times \sigma /$ $\mathrm{S}$ and $\mathrm{LOQ}=10 \times \sigma / \mathrm{S}$, where $\sigma=$ Standard deviation, $\mathrm{S}=$ Slope

\subsubsection{Heavy metals}

The samples were digested in nitric acid for mercury $(\mathrm{Hg})$ and in aquaregia for lead $(\mathrm{Pb}$ ), cadmium (Cd) and arsenic (As) using microwave assisted digestion system (MARS 6, CEM Corporation, USA) at pressure $650 \mathrm{psi}$ and temperature $120^{\circ} \mathrm{C}$. The digested samples were then filtered, volume made up to $25 \mathrm{ml}$ with distilled water and analysed using ICP-OES (AVIVO 200, Perkin Elmer, USA) (API, 2008).

\subsubsection{Aflatoxins}

The test of aflatoxins B1, B2, G1 and G2 in the formulation was performed using HPTLC as per method prescribed in The Ayurvedic Pharmacopoeia of India (API, 2008).

Test solution: The formulation was extracted with a $200 \mathrm{ml}$ mixture of methanol and water (17:3) by shaking vigorously by mechanical means for $30 \mathrm{~min}$ and then filtered. The filtrate was transferred to a separatory funnel. Then sodium chloride solution and hexane was added to it and shaken for $1 \mathrm{~min}$. It was allowed to separate into two layers and the lower aqueous layer was transferred to a second separatory funnel. This lower aqueous layers, the extracted twice with methylene chloride, by shaking for $1 \mathrm{~min}$. After separation into two layers, the lower organic layers were collected each time and combined in conical flask. Then, the organic solvent was evaporated to dryness on a water bath. Then, it was cooled and the residue obtained was dissolved in a mixture of chloroform and acetonitrile (9.8: 0.2$)$.

Aflatoxin standard solution: $1 \mathrm{ml}$ of aflatoxin mix 4 (B1, B2, G1 and G2) analytical standard solution was diluted to $10 \mathrm{ml}$ with distilled water to get concentrations $0.2 \mathrm{ug} / \mathrm{ml}, 0.2 \mathrm{ug} / \mathrm{ml}, 0.05 \mathrm{ug} /$ $\mathrm{ml}$ and $0.05 \mathrm{ug} / \mathrm{ml}$ of aflatoxin B1, B2, G1 and G2, respectively.

The volumes of $1 \mu 1,1.5 \mu 1,2 \mu 1$ and $2.5 \mu 1$ of aflatoxin standard solution and $10 \mu \mathrm{l}$ test solution was applied on a silica gel plate using sample applicator linomat 5. The plate was allowed to dry the spots and the chromatogram developed in an unsaturated chamber containing a solvent system consisting of a mixture of chloroform, acetone and isopropyl alcohol (85:10:5) until the solvent front moved not less than $15 \mathrm{~cm}$ from the origin. The plate was removed from the developing chamber, marked with solvent front and was allowed to air-dry. The spots were located on the plate by examination under UV light at $365 \mathrm{~nm}$ : the four applications of the aflatoxin solution appeared as four clearly separated blue fluorescent spots; the spot obtained from the test solution was superimposed on the aflatoxin solution was compared with corresponding aflatoxin solution. All the spots of the test solutions were compared with the spots obtained from the applications of the aflatoxin standard solution.

\subsubsection{Microbial load}

The total number of viable aerobic micro-organisms and test for presence of specific micro-organisms was carried out as per Ayurvedic Pharmacopoeia of India (API, 2008). It included total microbial plate count, total yeast and mould count, and presence of specific micro-organisms like Escherichia coli, Staphylococcus aureus, Salmonella sp. and Pseudomonas aeruginosa.

\subsubsection{Antimicrobial activity}

The different concentrations of formulation $(100 \mathrm{mg} / \mathrm{ml}, 300 \mathrm{mg} / \mathrm{ml}$, $500 \mathrm{mg} / \mathrm{ml}, 700 \mathrm{mg} / \mathrm{ml}$ and $900 \mathrm{mg} / \mathrm{ml}$ ) were prepared by diluting it with distilled water. Nutrient agar plates were prepared by pouring $15 \mathrm{ml}$ previously autoclaved nutrient agar into petridishes under aseptic condition and allowed to stand for room temperature for stabilization. Microbial cell cultures were used by regular subculturing on nutrient agar and were incubated at $37^{\circ} \mathrm{C}$ for $24 \mathrm{~h}$. Agar plates were inoculated by streaking the swab of microbial strains over the entire sterile agar surface 2-3 times for uniform distribution of the inoculum. The plates were dried at room temperature under aseptic condition and sterile $9 \mathrm{~mm}$ borer was used to bore the well in each of plates, $100 \mathrm{ul}$ of different concentrations of formulation ( $\mathrm{viz}$, $100 \mathrm{mg} / \mathrm{ml}, 300 \mathrm{mg} / \mathrm{ml}, 500 \mathrm{mg} / \mathrm{ml}, 700 \mathrm{mg} / \mathrm{ml}$ and $900 \mathrm{mg} / \mathrm{ml}$ ) and standard drug azithromycin $(10 \mathrm{mg} / \mathrm{ml})$ were added in wells by using sterile micropipette. The plates were then incubated at $37^{\circ} \mathrm{C}$ for 48 $\mathrm{h}$. The antimicrobial activity was determined by measuring diameter of zone of inhibition in mm (Parekh and Chanda, 2007; Dev et al., 2019; Nipanikar et al., 2017).

\section{Results}

\subsection{Organoleptic evaluation}

In the organoleptic evaluation of Mahamanjishthadi kadha, all samples were found to be brown colour with bitter and astringent taste and had characteristic fermented odour of added herbal ingredients.

\subsection{Physicochemical evaluation}

Physicochemical analysis of Mahamanjishthadi kadha showed the $\mathrm{pH}$ of formulation 4.3, 4.39 and 4.33. Alcohol content was found to be $9.68 \%, 8.58 \%$ and $8.85 \%$ and Brix was $32 \%, 30 \%$ and $31 \%$ for Batch I, II and III, respectively. The specific gravity was found to be $1.08 \mathrm{~g} / \mathrm{ml}$ for all the three batches. The results of the organoleptic and physicochemical analysis are tabulated in Table 2.

Table 2: Results of organoleptic and and physicochemical analysis of Mahamanjishthadi kadha

\begin{tabular}{|l|l|l|l|}
\hline Test & \multicolumn{3}{|c|}{ Observation } \\
\hline Batch No. & Batch I & Batch II & Batch III \\
\hline Colour & $\begin{array}{l}\text { Brown } \\
\text { coloured liquid }\end{array}$ & $\begin{array}{l}\text { Brown } \\
\text { coloured liquid }\end{array}$ & $\begin{array}{l}\text { Brown } \\
\text { coloured liquid }\end{array}$ \\
\hline Odour & Fermented & Fermented & Fermented \\
\hline Taste & $\begin{array}{l}\text { bitter and } \\
\text { astringent. }\end{array}$ & $\begin{array}{l}\text { bitter and } \\
\text { astringent }\end{array}$ & $\begin{array}{l}\text { bitter and } \\
\text { astringent }\end{array}$ \\
\hline pH & 4.3 & 4.39 & 4.33 \\
\hline Brix (\%) & 32 & 30 & 31 \\
\hline $\begin{array}{l}\text { Alcohol content } \\
(\% \mathbf{\%} \text { v) }\end{array}$ & 9.68 & 8.58 & 8.85 \\
\hline $\begin{array}{l}\text { specific gravity } \\
\left(\text { at } 25^{\circ} \mathbf{C}\right)\end{array}$ & 1.08 & 1.08 & 1.08 \\
\hline
\end{tabular}




\subsection{Phytochemical screening}

Qualitative phytochemical analysis of Mahamanjishthadi kadha showed the presence of phytoconstituents like alkaloids, steroids, triterpenoids, tannins, phenolic compounds, saponins and flavonoids. The results are presented in Table 3.

Table 3: Phytochemical screening of Mahamanjishthadi kadha

\begin{tabular}{|l|l|l|l|l|l|}
\hline Sr. No. & Parameters & Test name & Batch I & Batch II & Batch III \\
\hline 1 & Alkaloids & Dragendorff's Test & + & + & + \\
2 & Steroids and Triterpenoids & Salkowski Test & + & + & + \\
3 & Tannins and Phenolic compounds & Alkaline Reagent Test & + & + & + \\
4 & Saponins & Frothing Test & + & + & + \\
5 & Flavonoids & Alkaline Reagent Test & + & + & + \\
\hline
\end{tabular}

\subsection{Quantification of phytochemicals by HPTLC}

HPTLC analysis of methanol extract of three batches of Mahamanjishthadi kadha was carried out along with ellagic acid, gallic acid and lupeol standard. The densitogram developed for all the three batches of Mahamanjishthadi kadha showed characteristic peak corresponding to ellagic acid, gallic acid and lupeol at the $\mathrm{Rf}$ $0.26 \pm 0.02$, $R f 0.36 \pm 0.02$ and $\operatorname{Rf} 0.55 \pm 0.02$, respectively (Figure 1). The spectral index confirmed that the peak obtained was that of ellagic acid, gallic acid and lupeol at wavelength $278 \mathrm{~nm}, 290 \mathrm{~nm}$ and $600 \mathrm{~nm}$, respectively (Figures 2 and 3).

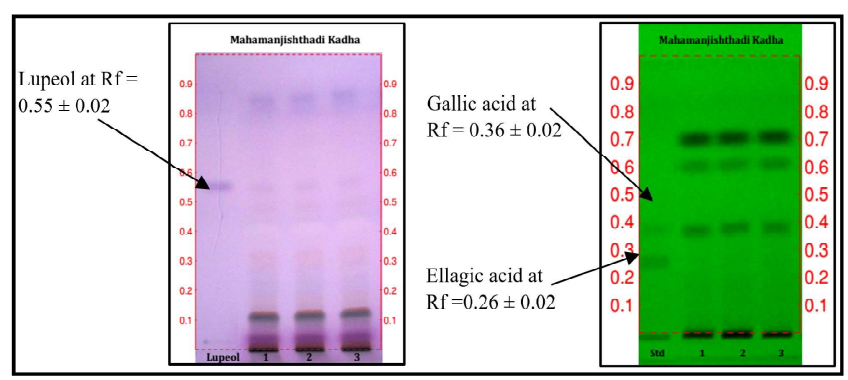

Figure 1: HPTLC plate of three batches (Batch I, Batch II, Batch III) of Mahamanjishthadi kadha with lupeol, gallic acid and ellagic acid markers.

\section{Method validation}

The HPTLC method was validated as per the ICH guidelines in terms of linearity, precision, robustness, accuracy, specificity, LOD (Limit of Detection) and LOQ (Limit of Quantification) as detailed below:

\section{Linearity}

Linearity between peak area and concentration of gallic acid, ellagic acid and lupeol in HPTLC analysis was observed to be linear in the range of $65.67 \mathrm{ng}-262.68 \mathrm{ng}$ for gallic acid, $33.27 \mathrm{ng}-116.45 \mathrm{ng}$ for

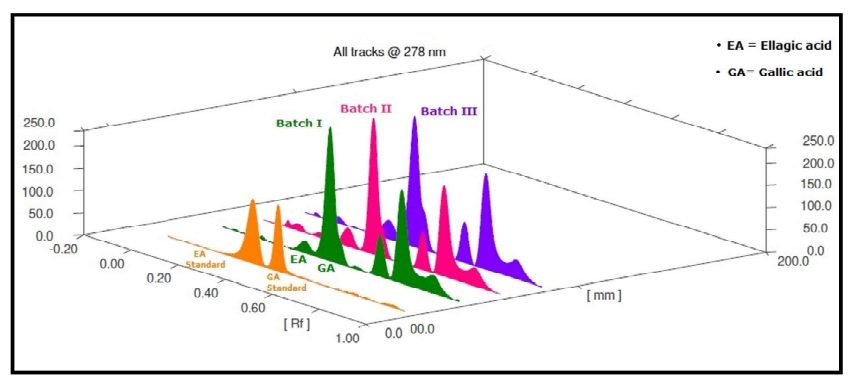

Figure 2: Densitogram of ellagic acid and gallic acid at $278 \mathrm{~nm}$ wavelength in Mahamanjishthadi kadha.

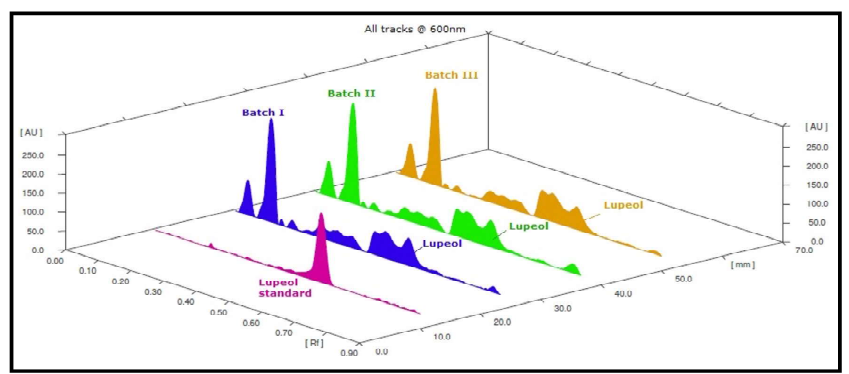

Figure 3: Densitogram of lupeol at $600 \mathrm{~nm}$ wavelength in Mahamanjishthadi kadha.

ellagic acid and $24.75 \mathrm{ng}-173.25 \mathrm{ng}$ for lupeol with correlation coefficient $r=0.9996,0.9997$ and 0.9994 , respectively (Table 4 and Figure 4).

The limit of detection (LOD) estimated for gallic acid, ellagic acid and lupeol was $7.03 \mathrm{ng} / \mathrm{spot}, 3.93 \mathrm{ng} / \mathrm{spot}, 5.74 \mathrm{ng} / \mathrm{spot}$, respectively and limit of quantification (LOQ) for gallic acid, ellagic acid and lupeol was reported as $21.32 \mathrm{ng} / \mathrm{spot}, 11.9 \mathrm{ng} / \mathrm{spot}, 17.38$ ng/spot, respectively (Table 4).

Table 4: Linear regression values with LOD and LOQ

\begin{tabular}{|l|l|l|l|l|}
\hline$\#$ & Parameters & \multicolumn{3}{|c|}{ Observed values } \\
\cline { 3 - 5 } & & Gallic acid & Ellagic acid & Lupeol \\
\hline 1 & Linearity range (ng/spot) & $65.67-262.68$ & $33.27-116.45$ & $24.75-173.25$ \\
2 & Correlation coefficient & 0.9996 & 0.9997 & 0.9994 \\
3 & Linear regression equation & Y $=-494.39+21.71 \mathrm{X}$ & $\mathrm{Y}=417.579+40.69 \mathrm{X}$ & $\mathrm{Y}=410.60+22.90 \mathrm{X}$ \\
4 & Slope \pm SD & 21.71 & 40.69 & 40.94 \\
5 & Intercept \pm SD & 670.54 & 417.579 & 410.6 \\
6 & LOD (ng/ul) & 7.03 & 3.93 & 5.74 \\
7 & LOQ (ng/ul) & 21.32 & 11.9 & 17.38 \\
\hline
\end{tabular}




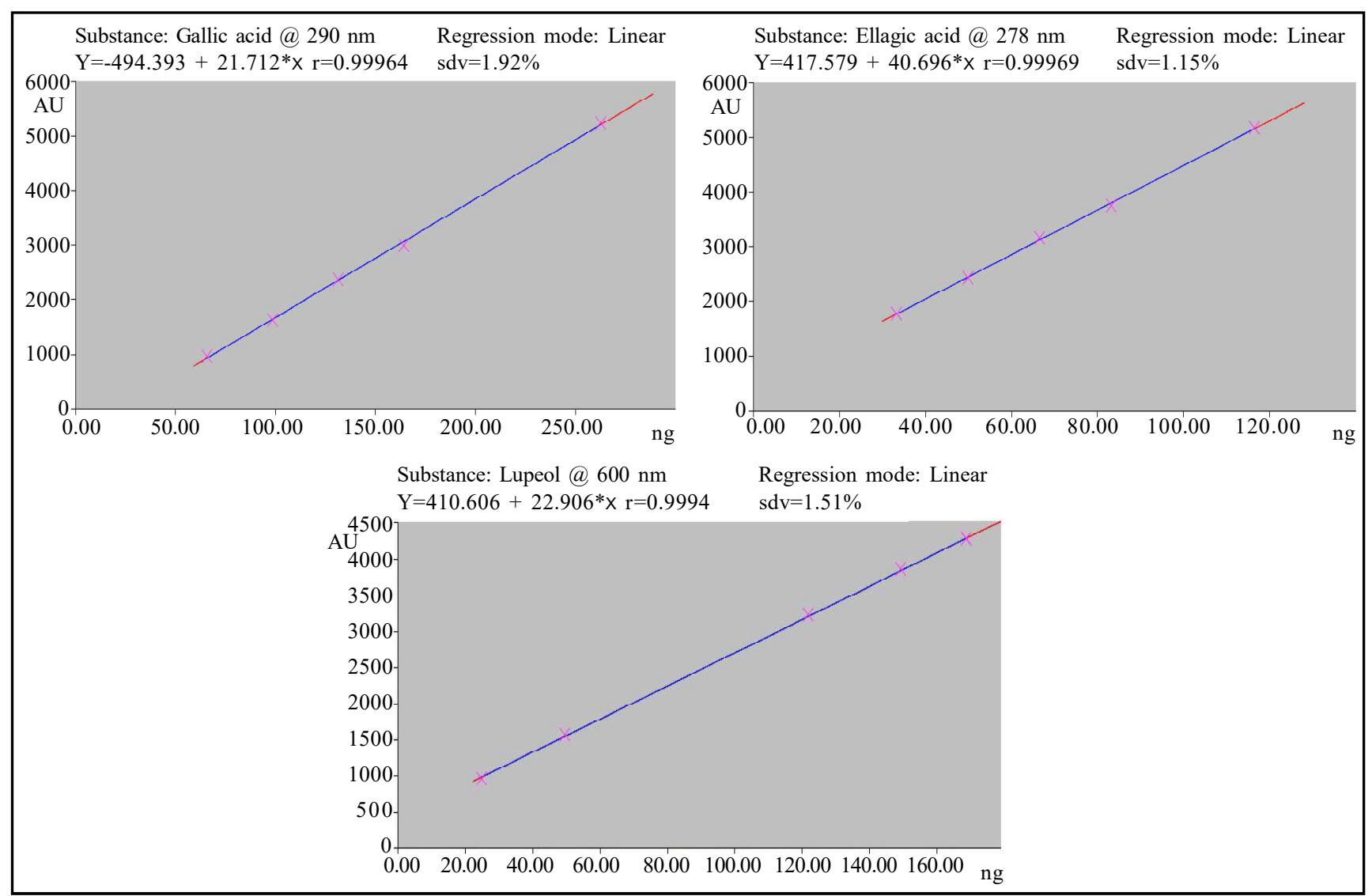

Figure 4: Calibration curve of standard gallic acid, ellagic acid and lupeol.

\section{Precision}

Precision of the HPTLC methods was validated in terms of repeatability (Method precision) and reproducibility (Intermediate precision).

\section{Method precision (Repeatability)}

Repeatability was evaluated by analysis of 10 sample with same concentration under same experimental conditions (Day, analyst, instrument and sample) and \% RSD was found to be $<2.00$. The results of precision of the method are presented in Table 5.

Table 5: Method precision (Repeatability) results

\begin{tabular}{|l|l|l|l|l|}
\hline Sa mple & & Gallic acid & Ellagic acid & Lupeol \\
\hline Mahamanjishthadi kadha Batch I & Sample quantity $(\mathrm{ml})$ & Peak area (AU) & Peak area (AU) & Peak area (AU) \\
\hline & 15 & 3704 & 2555.2 & 2158.3 \\
& 15 & 3715 & 2519 & 2138.9 \\
& 15 & 3648.5 & 2489.9 & 2258 \\
& 15 & 3687.5 & 2586.5 & 2268 \\
& 15 & 3781 & 2448.9 & 2231.5 \\
& 15 & 3709.5 & 2505.4 & 2211.6 \\
& 15 & 3612.5 & 2498.5 & 2178 \\
& 15 & 3708.4 & 2543.1 & 2188.9 \\
& 15 & 3652.8 & 2529.3 & 2198.5 \\
& 15 & 3641.9 & 2478.8 & 2205.2 \\
& Mean & $\mathbf{3 6 8 6 . 1 1}$ & $\mathbf{2 5 1 5 . 4 6}$ & $\mathbf{2 2 0 3 . 6 9}$ \\
& SD & $\mathbf{4 8 . 4 2 1 4}$ & $\mathbf{4 0 . 0 1 4 4}$ & $\mathbf{4 0 . 9 4 3 4}$ \\
& \% RSD & $\mathbf{1 . 3 1}$ & $\mathbf{1 . 5 9}$ & $\mathbf{1 . 8 6}$ \\
\hline
\end{tabular}

\section{Intermediate precision (Reproducibility)}

Intermediate precision data were subdivided into intraday precision and interday precision. Intraday precision was obtained by analysing the same sample three times within 1day. Interday precision performed for 3 different days, using freshly prepared samples and mobile phases. The RSD values obtain during the interday and intraday intermediate precision was $<2.0 \%$ (Tables 6 and 7). 
Table 6: Intraday precision results

\begin{tabular}{|c|c|c|c|c|c|c|}
\hline \multirow{4}{*}{ Gallic acid } & Batch I sample (1 ul/spot) & Level & Peak area (AU) & mean & Standard deviation & $\%$ RSD \\
\hline & Sample 1 & $\begin{array}{l}\text { Session } 1 \\
\text { Session } 2 \\
\text { Session } 3\end{array}$ & $\begin{array}{l}3704 \\
3739.4 \\
3698.4\end{array}$ & 3713.93 & 22.23 & 0.6 \\
\hline & Sample 2 & $\begin{array}{l}\text { Session } 1 \\
\text { Session } 2 \\
\text { Session } 3 \\
\end{array}$ & $\begin{array}{l}3791.5 \\
3724.4 \\
3712.8 \\
\end{array}$ & 3742.9 & 42.49 & 1.14 \\
\hline & Sample 3 & $\begin{array}{l}\text { Session } 1 \\
\text { Session } 2 \\
\text { Session } 3\end{array}$ & $\begin{array}{l}3895.5 \\
3837.5 \\
3788.7\end{array}$ & 3840.57 & 53.47 & 1.39 \\
\hline \multirow{4}{*}{ Ellagic acid } & Batch I sample (1 ul/spot) & Level & Peak area (AU) & mean & Standard deviation & $\%$ RSD \\
\hline & Sample 1 & $\begin{array}{l}\text { Session } 1 \\
\text { Session } 2 \\
\text { Session } 3\end{array}$ & $\begin{array}{l}2548.9 \\
2525.3 \\
2561.5\end{array}$ & 2545.23 & 18.38 & 0.72 \\
\hline & Sample 2 & $\begin{array}{l}\text { Session } 1 \\
\text { Session } 2 \\
\text { Session } 3 \\
\end{array}$ & $\begin{array}{l}2411.1 \\
2400.8 \\
2421.2 \\
\end{array}$ & 2411.03 & 10.2 & 0.42 \\
\hline & Sample 3 & $\begin{array}{l}\text { Session } 1 \\
\text { Session } 2 \\
\text { Session } 3\end{array}$ & $\begin{array}{l}2218.5 \\
2266.9 \\
2248.5\end{array}$ & 2244.63 & 24.43 & 1.09 \\
\hline \multirow{4}{*}{ Lupeol } & Batch I sample (1 ul/spot) & Level & Peak area (AU) & mean & Standard deviation & $\%$ RSD \\
\hline & Sample 1 & $\begin{array}{l}\text { Session } 1 \\
\text { Session } 2 \\
\text { Session } 3\end{array}$ & $\begin{array}{l}2268 \\
2210 \\
2198.5\end{array}$ & 2225.5 & 37.25 & 1.67 \\
\hline & Sample 2 & $\begin{array}{l}\text { Session } 1 \\
\text { Session } 2 \\
\text { Session } 3 \\
\end{array}$ & $\begin{array}{l}2400.8 \\
2395.6 \\
2468.5 \\
\end{array}$ & 2421.63 & 40.67 & 1.68 \\
\hline & Sample 3 & $\begin{array}{l}\text { Session } 1 \\
\text { Session } 2 \\
\text { Session } 3\end{array}$ & $\begin{array}{l}2501 \\
2488.9 \\
2551.5\end{array}$ & 2513.8 & 33.2 & 1.32 \\
\hline
\end{tabular}

Table 7: Intraday precision results

\begin{tabular}{|c|c|c|c|c|c|c|}
\hline \multirow{4}{*}{ Gallic acid } & Batch I sample (1 ul/spot) & Day & Peak area (AU) & mean & Standard deviation & \% RSD \\
\hline & Sample 1 & $\begin{array}{l}\text { Day } 1 \\
\text { Day } 2 \\
\text { Day } 3\end{array}$ & $\begin{array}{l}3704 \\
3758.5 \\
3715.9 \\
\end{array}$ & 3726.13 & 28.65 & 0.77 \\
\hline & Sample 2 & $\begin{array}{l}\text { Day } 1 \\
\text { Day } 2 \\
\text { Day } 3\end{array}$ & $\begin{array}{l}3791.5 \\
3724.4 \\
3712.8\end{array}$ & 3742.9 & 42.49 & 1.14 \\
\hline & Sample 3 & $\begin{array}{l}\text { Day } 1 \\
\text { Day } 2 \\
\text { Day } 3\end{array}$ & $\begin{array}{l}3895.5 \\
3837.5 \\
3788.7\end{array}$ & 3840.57 & 53.47 & 1.39 \\
\hline \multirow{4}{*}{ Ellagic acid } & Batch I sample (1 ul/spot) & Level & Peak area (AU) & mean & Standard deviation & $\%$ RSD \\
\hline & Sample 1 & $\begin{array}{l}\text { Day } 1 \\
\text { Day } 2 \\
\text { Day } 3\end{array}$ & $\begin{array}{l}2548.9 \\
2510.5 \\
2568.5 \\
\end{array}$ & 2542.63 & 29.5 & 1.16 \\
\hline & Sample 2 & $\begin{array}{l}\text { Day } 1 \\
\text { Day } 2 \\
\text { Day } 3\end{array}$ & $\begin{array}{l}2411.1 \\
2401.8 \\
2478.5\end{array}$ & 2430.47 & 41.86 & 1.72 \\
\hline & Sample 3 & $\begin{array}{l}\text { Day } 1 \\
\text { Day } 2 \\
\text { Day } 3 \\
\end{array}$ & $\begin{array}{l}2266.9 \\
2212.1 \\
2248.5 \\
\end{array}$ & 2242.5 & 27.89 & 1.24 \\
\hline \multirow{4}{*}{ Lupeol } & Batch I sample (1 ul/spot) & Level & Peak area (AU) & mean & Standard deviation & $\%$ RSD \\
\hline & Sample 1 & $\begin{array}{l}\text { Day } 1 \\
\text { Day } 2 \\
\text { Day } 3\end{array}$ & $\begin{array}{l}2268 \\
2198.5 \\
2279.7 \\
\end{array}$ & 2248.73 & 43.89 & 1.95 \\
\hline & Sample 2 & $\begin{array}{l}\text { Day } 1 \\
\text { Day } 2 \\
\text { Day } 3 \\
\end{array}$ & $\begin{array}{l}2412.5 \\
2478.3 \\
2501 \\
\end{array}$ & 2463.93 & 45.97 & 1.87 \\
\hline & Sample 3 & $\begin{array}{l}\text { Day } 1 \\
\text { Day } 2 \\
\text { Day } 3\end{array}$ & $\begin{array}{l}2558.1 \\
2599.3 \\
2647\end{array}$ & 2601.47 & 44.49 & 1.71 \\
\hline
\end{tabular}




\section{Accuracy}

The accuracy of the method was determined by standard addition method. The known amounts of standard were spiked with sample solution. The calculated amount was compared with the experimentally determined amount. The percentage recovery was calculated for gallic acid, ellagic acid and lupeol which was found to be in the range of $95-97 \%, 90-94 \%$ and $92 \%$ - 98\%, respectively. The percentage RSD for ellagic acid, gallic acid and lupeol was found to be $<2 \%$ (Table 8 ).

Table 8: Percentage recovery of gallic acid, ellagic acid and lupeol

\begin{tabular}{|l|l|l|l|l|l|l|}
\hline Phytochemicals & $\begin{array}{l}\text { Amount of marker } \\
\text { in sample (ng) }\end{array}$ & $\begin{array}{l}\text { Amount of standard } \\
\text { added (ng) }\end{array}$ & $\begin{array}{l}\text { Theoretical } \\
\text { amount (ng/ul) }\end{array}$ & $\begin{array}{l}\text { Analysed } \\
\text { amount (ng/ul) }\end{array}$ & \% recovery & \% RSD \\
\hline \multirow{3}{*}{ Gallic acid } & 38.4 & 3.50 & 41.90 & 40.10 & 95.71 & 1.89 \\
& 38.4 & 7.00 & 45.40 & 43.73 & 96.32 & 1.31 \\
& 38.4 & 2.00 & 52.40 & 50.48 & 96.33 & 1.94 \\
\hline \multirow{3}{*}{ Ellagic acid } & 10.2 & 4.00 & 12.20 & 11.01 & 90.25 & 1.53 \\
& 10.2 & 8.00 & 14.20 & 13.11 & 92.3 & 1.34 \\
\hline \multirow{2}{*}{ Lupeol } & 10.2 & 0.50 & 3.92 & 3.0 & 93.88 & 1.56 \\
& 3.42 & 1.00 & 4.42 & 4.30 & 93.28 & 1.6 \\
& 3.42 & 2.00 & 5.42 & 5.00 & 97.36 & 1.49 \\
& 3.42 & & & 92.19 & 1.67 \\
\hline
\end{tabular}

\section{Specificity}

The identity of the gallic acid, ellagic acid and lupeol in the Mahamanjishthadi kadha was demonstrated by comparing the Rf value and the spectra with those of standard solutions.
Absorption maxima of $290 \mathrm{~nm}$ for gallic acid, $272 \mathrm{~nm}$ for ellagic acid and of $600 \mathrm{~nm}$ for lupeol were verified. The spectra of standard gallic acid, ellagic acid and lupeol were identical with the spectra of those compounds in Mahamanjishthadi kadha (Figure 5). Thus, the methods are specific for gallic acid, ellagic acid and lupeol.
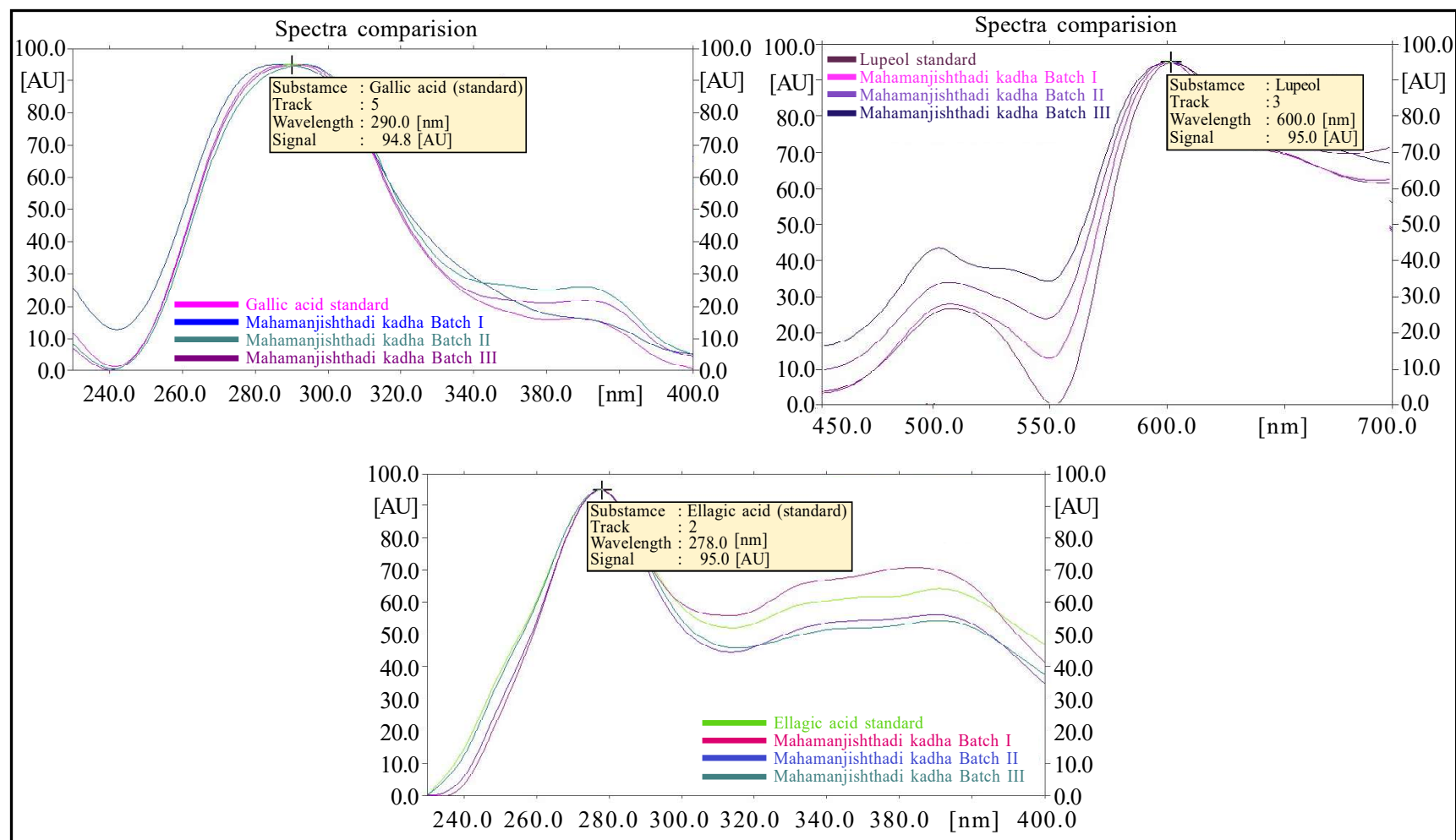

Figure 5: Overlay spectra of standard gallic acid, ellagic acid and lupeol in Mahamanjishthadi kadha.

\subsection{Heavy metals}

Heavy metal analysis of Mahamanjishthadi kadha for Batch I, II and III performed by ICP-OES has been reported in Table 9.

Lead $(\mathrm{Pb})$ was reported $<0.2 \mathrm{ppm}$ in all the three batches tested. Similarly, mercury ( $\mathrm{Hg}$ ), was reported $<0.002 \mathrm{ppm}$, arsenic (As) $<0.01 \mathrm{ppm}$ and cadmium $(\mathrm{Cd})<0.1 \mathrm{ppm}$.
Table 9: Results of heavy metal analysis

\begin{tabular}{|l|l|l|l|}
\hline Heavy metal & \multicolumn{3}{|c|}{ Observed value (ppm) } \\
\hline & Batch I & Batch II & Batch III \\
\hline Lead $(\mathrm{Pb})$ & 0.195 & 0.180 & 0.187 \\
Mercury $(\mathrm{Hg})$ & 0.0021 & 0.0018 & 0.0025 \\
Arsenic (As) & 0.0142 & 0.0135 & 0.0165 \\
Cadmium $(\mathrm{Cd})$ & $<0.1$ & $<0.1$ & $<0.1$ \\
\hline
\end{tabular}




\subsection{Aflatoxins}

Aflatoxins, viz., B1, B2, G1 and G2 were analyzed in all three batches using HPTLC as per method prescribed in The Ayurvedic Pharmacopoeia of India (API). TLC plate examined under $365 \mathrm{~nm}$ did not show any fluorescent blue spot for all the three samples under test when compared with that of corresponding reference standards (Table 10).

Table 10: Results of aflatoxins analysis

\begin{tabular}{|l|l|l|l|l|l|}
\hline \multirow{2}{*}{$\begin{array}{l}\text { No. } \\
\text { No. }\end{array}$} & Aflatoxins & \multicolumn{4}{|c|}{ Under UV at 365 nm } \\
\cline { 3 - 6 } & & $\begin{array}{l}\text { Reference } \\
\text { Standard }\end{array}$ & Batch I & Batch II & Batch III \\
\hline 1 & $\mathrm{~B}_{1}$ & + & - & - & - \\
2 & $\mathrm{~B}_{2}$ & + & - & - & - \\
3 & $\mathrm{G}_{1}$ & + & - & - & - \\
4 & $\mathrm{G}_{2}$ & + & - & - & - \\
\hline
\end{tabular}

'+' = Presence of Aflatoxins and ' - ' $=$ Absence of Aflatoxins.

\subsection{Antimicrobial activity}

The antimicrobial activity study was performed in the different concentrations of Mahamanjisthadi kadha $(100 \mathrm{mg} / \mathrm{ml}, 300 \mathrm{mg} / \mathrm{ml}, 500$ $\mathrm{mg} / \mathrm{ml}, 700 \mathrm{mg} / \mathrm{ml}$ and $900 \mathrm{mg} / \mathrm{ml}$ ) against four bacterial strains, S. aureus, S. epidermidis, P. aeruginosa, E. Coli and one fungal strain C. albicans. It was observed that the zone of inhibition increased as the concentration of formulation increased. $900 \mathrm{mg} / \mathrm{ml}$ concentration of Mahamanjishthadi kadha exhibited the significant antibacterial activity against $S$. aureus, $S$. epidermidis, $P$. aeruginosa, and $C$. albicans with zone of inhibition ranges from $24 \mathrm{~mm}$ to $30 \mathrm{~mm}$ for all the three batches.

The zone of inhibition for $500 \mathrm{mg} / \mathrm{ml}$ and $700 \mathrm{mg} / \mathrm{ml}$ concentration were observed in range of $18 \mathrm{~mm}-28 \mathrm{~mm}$. Whereas, $100 \mathrm{mg} / \mathrm{ml}$

\subsection{Microbial load}

Microbial analysis of all the three batches of Mahamanjishthadi kadha showed total plate count as $<10$ c.f.u./g. Yeast and moulds counts were reported as $<10$ c.f.u./g. The pathogenic bacteria, Escherichia coli, Salmonella Spp, Staphylococcus aureus and Pseudomonas aeruginosa were found to be absent in the test samples of formulation (Table 11).

Table 11: Result of microbial analysis

\begin{tabular}{|c|c|c|c|c|}
\hline \multirow{2}{*}{$\begin{array}{l}\text { S. } \\
\text { No. }\end{array}$} & \multirow[t]{2}{*}{ Parameters } & \multicolumn{3}{|c|}{ Observed value } \\
\hline & & Batch I & Batch II & Batch III \\
\hline 1 & $\begin{array}{l}\text { Total microbial plate } \\
\text { count (TPC) }\end{array}$ & $<10$ c.f.u. $/ g$ & $<10$ c.f.u./g & $<10$ c.f.u./g \\
\hline 2 & Total yeast and mould & $<10$ c.f.u./g & $<10$ c.f.u./g & $<10$ c.f.u. $/ g$ \\
\hline 3 & $\begin{array}{l}\text { Staphylococcus } \\
\text { aureus/g }\end{array}$ & Absent & Absent & Absent \\
\hline 4 & Salmonella sp./g & Absent & Absent & Absent \\
\hline 5 & $\begin{array}{l}\text { Pseudomonas } \\
\text { aeruginosa/g }\end{array}$ & Absent & Absent & Absent \\
\hline 6 & Escherichia coli & Absent & Absent & Absent \\
\hline
\end{tabular}

concentration of formulation exhibited antimicrobial activity with least zone of inhibition against $S$. Epidermidis and $C$. albicans and no zone of inhibition was observed against $P$. aeruginosa and $S$. aureus. Azithromycin shows its maximum antimicrobial efficacy as standard drug compared to formulation. E coli was found resistant to the formulation as no clear zone of inhibition observed.

The zone of inhibition of Mahamanjishthadi kadha against different micro-organisms are shown in Figure 6 and the results of the antibacterial and antifungal activities are presented in Table 12.

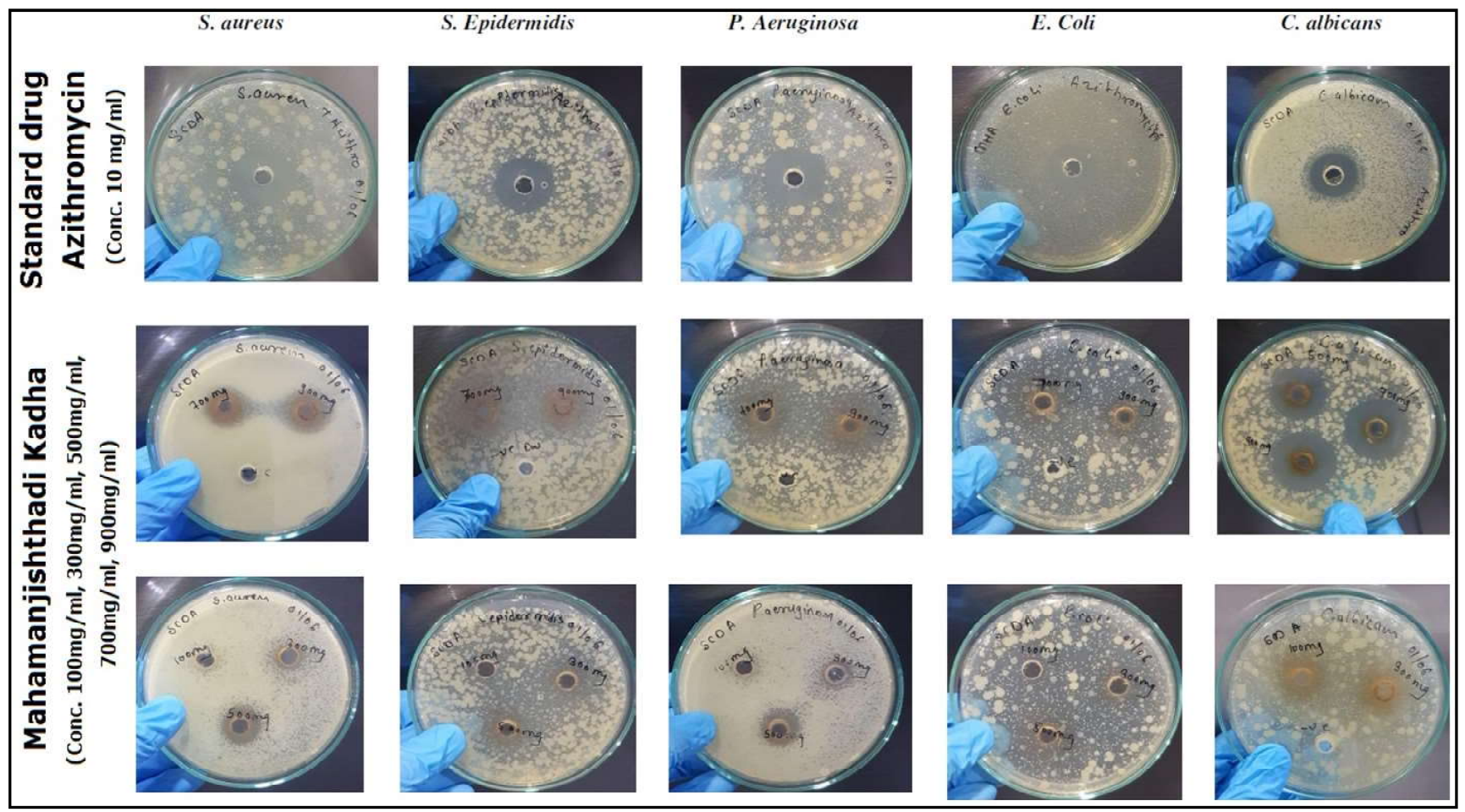

Figure 6: In vitro culture plate (Well-diffusion method) of aqueous extract of Mahamanjishthadi kadha (at concentration $100 \mathrm{mg} / \mathrm{ml}, 300 \mathrm{mg} / \mathrm{ml}$, $500 \mathrm{mg} / \mathrm{ml}, 700 \mathrm{mg} / \mathrm{ml}$ and $900 \mathrm{mg} / \mathrm{ml}$ ) and standard drug azithromycin showing zone of inhibition against S. aureus, S. epidermidis, P. aeruginosa, E. coli and C. albicans. 
Table 12: Results of analysis of antimicrobial activity

\begin{tabular}{|c|c|c|c|c|c|c|c|}
\hline \multicolumn{8}{|c|}{ Zone of inhibition $(\mathrm{mm})($ Mean \pm SD) } \\
\hline & $\begin{array}{l}\text { Concentration } \\
\text { of formulation }\end{array}$ & $100 \mathrm{mg} / \mathrm{ml}$ & $300 \mathrm{mg} / \mathrm{ml}$ & $500 \mathrm{mg} / \mathrm{ml}$ & $700 \mathrm{mg} / \mathrm{ml}$ & $900 \mathrm{mg} / \mathrm{ml}$ & $\begin{array}{c}\text { Azithromycin } \\
(10 \mathrm{mg} / \mathrm{ml})\end{array}$ \\
\hline P. aeruginosa & \begin{tabular}{|l|} 
Batch I \\
Batch II \\
Batch III
\end{tabular} & $\begin{array}{c}\text { No zone } \\
\text { of inhibition }\end{array}$ & $\begin{aligned} 12.9 & \pm 0.15 \\
12.93 & \pm 0.11 \\
13.16 & \pm 0.28\end{aligned}$ & $\begin{aligned} 18.13 & \pm 0.32 \\
18 & \pm 0.2 \\
18.13 & \pm 0.32\end{aligned}$ & $\begin{aligned} 23.2 & \pm 0.26 \\
23.23 & \pm 0.25 \\
23.13 & \pm 0.11\end{aligned}$ & $\begin{aligned} 25.13 & \pm 0.23 \\
25.16 & \pm 0.20 \\
25.2 & \pm 0.26\end{aligned}$ & $26 \pm 0.12$ \\
\hline S. aureus & \begin{tabular}{|l|} 
Batch I \\
Batch II \\
Batch III
\end{tabular} & $\begin{array}{c}\text { No zone } \\
\text { of inhibition }\end{array}$ & $\begin{aligned} 15.2 & \pm 0.26 \\
15.13 & \pm 0.15 \\
15.26 & \pm 0.20\end{aligned}$ & $\begin{array}{l}18.23 \pm 0.25 \\
18.33 \pm 0.28 \\
18.23 \pm 0.25\end{array}$ & $\begin{aligned} 19.96 & \pm 0.05 \\
20.13 & \pm 0.15 \\
20.1 & \pm 0.17\end{aligned}$ & $\begin{aligned} 24.03 & \pm 0.05 \\
24.03 & \pm 0.20 \\
24.1 & \pm 0.10\end{aligned}$ & $28.96 \pm 0.15$ \\
\hline S. epidermids & \begin{tabular}{|l|} 
Batch I \\
Batch II \\
Batch III
\end{tabular} & $\begin{aligned} 16.2 & \pm 0.26 \\
16.23 & \pm 0.23 \\
16.2 & \pm 0.26\end{aligned}$ & $\begin{aligned} 20.13 & \pm 0.15 \\
20.16 & \pm 0.15 \\
20.1 & \pm 0.17\end{aligned}$ & $\begin{array}{l}25.06 \pm 0.11 \\
25.36 \pm 0.32 \\
25.06 \pm 0.11\end{array}$ & $\begin{array}{l}28.03 \pm 0.05 \\
28.03 \pm 0.05 \\
28.43 \pm 0.45\end{array}$ & $\begin{aligned} 29.96 & \pm 0.15 \\
29.96 & \pm 0.05 \\
30 & \pm 0.20\end{aligned}$ & $25.03 \pm 0.12$ \\
\hline C. albicans & \begin{tabular}{|l|} 
Batch I \\
Batch II \\
Batch III
\end{tabular} & $\begin{array}{l}16.1 \pm 0.1 \\
16.2 \pm 0.1 \\
16.2 \pm 0.26\end{array}$ & $\begin{array}{r}19.3 \pm 0.40 \\
19.96 \pm 0.15 \\
19.8 \pm 0.34\end{array}$ & $\begin{aligned} 25.1 & \pm 0.10 \\
25.16 & \pm 0.20 \\
24.93 & \pm 0.11\end{aligned}$ & $\begin{array}{l}27.96 \pm 0.15 \\
27.96 \pm 0.15 \\
27.93 \pm 0.11\end{array}$ & $\begin{array}{l}30.03 \pm 0.20 \\
30.06 \pm 0.20 \\
29.96 \pm 0.15\end{array}$ & $28.03 \pm 0.60$ \\
\hline
\end{tabular}

\section{Disscussion}

In this present study, an Ayurvedic formulation, Mahamanjisthadi kadha was analysed for physicochemical and phytochemical parameters as well as for contaminants such as heavy metals, alfatoxin and microbial load as per guidelines specified in The Ayurvedic Pharmacopoeia of India (API). The guidelines of standardization published by International Council for Harmonisation (ICH), World Health Organization (WHO) and United States Pharmacopoeia (USP) were also referred (ICH, 2005; WHO, 1998; Mukharjee, 2002). The antimicrobial effect of the formulation was also evaluated on pathogens causing various skin related ailments.

Each Ayurvedic formulation has a characteristic organoleptic property of taste, color, odor, appearance and is expected to show consistency in all batches manufactured. Any deviation in these aspects gives an indication of quality deviation. Ayurvedic medicines are being assessed qualitatively since centuries and it serves an important parameter of primary quality evaluation. Hence, the characteristic organoleptic properties are reported in our work.

Preliminary tests and physicochemical evaluation findings help in depth investigations and facilitate the standardization of formulation at industrial level. The $\mathrm{pH}$ for Asava, Arishta and kadha is very important parameter which not only effects aroma, flavour, colour but other quality aspects like stability and maturity. Many pathogenic micro-organisms are unable to multiply at $\mathrm{pH}$ of 3-5. Thus, a stable $\mathrm{pH}$ in Asava, Arishta and kadha gives natural protection against pathogenic micro-organisms. $\mathrm{pH}$ also contributes to chemical reactions that takes place in Asava, Arishta and kadha during and after fermentation. Brix is reported as "\% Brix" and is equivalent to percentage of total soluble solids in a solution (like Syrup, Elixirs, etc.). These soluble solids are mainly sugar and its constituents like glucose, fructose and maltose. In case of Asava, Arishta and kadha it also includes soluble solids extracted from its herbal ingredients.

Specific gravity of liquid is the mass of a given volume of material in reference to the mass of water. In the case of Asava, Arishta and kadha, there are several factors which can contribute to the density before fermentation and after fermentation. There are sugars, unfermentable herbal materials, extracts, starches and oils, minerals, and other ingredients which contribute to the density of the Asava, Arishta and kadha. If, specific gravity readings vary significantly from expected specifications, there are many possible factors. It could be that sugar conversion was more or less complete, or that ingredients had a lower or higher yield during the conversion process. The self generated alcohol in Asava, Arishta and kadha has vital role in quality and efficacy of formulations. It serves in enhancing the shelf life by inhibiting the growth of the various microbes and is known to keep the quality intact for at least 10 years (Government of India, 2016).

Besides quality aspect, this formulation is required to comply with legal requirementsas per Drugs and Cosmetics Acts, 1940 and Rules 1945 which regulates the upper limit of alcohol as self generated alcohol should not exceed 12\% v/v (Deshpande and Gandhi, 2018).

As these physicochemical parameters are known to contribute in quality, Mahamanjisthadi kadha was standardized for $\mathrm{pH}$, alcohol content, brix and specific gravity (at $25^{\circ}$ ).

Phytochemicals present in the plants naturally play a major role in therapeutic efficacy of formulation prepared from them. Various studies conducted on phytochemical screening have shown the presence of secondary plant metabolites such as phenols, flavonoids, terpenoids, glycosides, alkaloids, tannins, saponins, various alcohols and related compounds in Asava, Aristha and kadha (Santosh et al., 2003; Rajlakshmy and Sindhu, 2011; Tiwariand Patel, 2011; Chacko et al., 2012; Kadam et al., 2012). Previous studies confirmed that these phytoconstituents play important role in various skin treatments (Kashif et al., 2017). Hence, the presence of these phytoconstituents in Mahamanjishtadi kadha as reported by its phytochemical screening contributes to its effectiveness in skin treatments.

HPTLC is an important tool used in standardization of product by the development of fingerprint profile, Quantification of phytoconstituents and determination of impurities. It is being used for both qualitative and quantitative analysis of all range of Ayurvedic formulations (Tablets, Choorna, Avaleha, Asavas and Syrup) and herbal raw materials. HPTLC analysis and validation of markers compounds plays a major role in standardization of poly herbal formulation (Rajani and Kanaki, 2008).

The main objective of the HPTLC study of Mahamnjishtadi kadha was to develop unique method for estimation of phytoconstituents such as lupeol, ellagic acid and gallic acid in the formulation. By 
trial with various solvent combinations, it was possible to establish the methods for confirmation and quantification of lupeol, gallic acid and ellagic acid in its methanolic extract. These methods were validated as per ICH guidelines (ICH, 2005).

The phytochemicals lupeol, ellagic acid and gallic acid have been reported to show effect in management of skin ailments (Malinowska et al., 2019; Varma et al., 2016). The presence of above phytochemicals in Mahamanjisthadi kadha as reported in HPTLC can be linked with its therapeutic index.

Heavy metals ( $\mathrm{Pb}, \mathrm{Hg}, \mathrm{Cd}$ and $\mathrm{As})$ are amongst the elements that have caused the most concern in terms of adverse effects on human health (Pilarczyk et al., 2013). These heavy metals have been listed in Ayurvedic Pharmacopoeia of India (API) with specified permissible limits, viz., lead $(\mathrm{Pb}) 10 \mathrm{ppm}$, mercury $(\mathrm{Hg}) 1 \mathrm{ppm}$, arsenic (As) 3 ppm, and cadmium (Cd) 0.3 ppm (API, 2018). Heavy metal analysis of Mahamanjisthadi kadha tested by ICP was found to comply with API limits.

As the formulation under study contained natural ingredients which are prone to be contaminated by micro flora from soil, water and air: the samples were subjected to test microbial load and pathogen test. The Ayurvedic Pharmacopoeia of India has defined the microbial contamination limits as total plate count (TPC) $10^{5} / \mathrm{g}$, total yeast and mould $10^{3} / \mathrm{g}$, and 4 pathogens should be absent $(S$. aureus $/ g$, Salmonella sp/g, P.aeruginosa $/ g$, E.coli/g). The formulation Mahamanjisthadi kadha tested were found to be as per the API limits which confirmed safety in terms of microbial contaminants (API, 2018).

Few Aspergillus species are known to produce toxic secondary metabolites- aflatoxins (B1, B2, G1 and G2). These mycotoxins can cause adverse health hazards which ranges from aflatoxicosis (acute poisoning), liver damage to genotoxic and carcinogenic effects. Aflatoxins pose a serious threat to both human beings and animals. WHO, along with FAO is involved in risk assessment of aflatoxins to humans through contamination in agro products, food, etc., and has recommended maximum permissible limits. WHO has suggested national regulatory authorities to monitor and ensure that levels of altaoxins are at minimal level and in compliance to national and international maximum levels, conditions and legislation (WHO, 2018).

Ayurvedic Pharmacoepia of India (API) has published specified permissible limits for aflatoxins (B1, G1 0.5 ppm and B2, G2 0.1 ppm) (API, 2008). The formulation Mahamanjisthadi kadha tested for aflatoxins (B1, B2, G1 and G2) were found to comply with these prescribed API limits.

So, the batches tested were found safe to consume as the concentration of heavy metal, microbial load and aflatoxins reported was either not detected or were found to be within permissible limits.

Plant derived phytoconstituents have been reported to show antioxidant and antimicrobial activities (Tumen et al., 2018; Deldar et al 2018; Zhao et al., 2018; Marques and Marques, 2018; Qu et al., 2018) and have been widely explored in treatment and management of skin ailments. Various secondary metabolites like flavonoids and phenolic compounds present in polyherbal formulations exhibit antioxidant and antimicrobial activity $(\mathrm{Qu}$ et al., 2018; Cushnie and Lamb, 2005; Lucchini and Corre, 1990). Tannin and its compounds present in Mahamanjisthadi kadha are potent cyclooxygenase-1 inhibitors with antiinflammatory and wound healing properties (Dev et al., 2019). Tannin has a property to form a complex with proteins, via, hydrogen bonding and hydrophobic effects. This ability to inactivate microbial enzymes and cell proteins is responsible for its antimicrobial property (Haslam, 1996). Studies conducted by Scalbert showed tannins can be toxic to filamentous fungi, yeasts, and bacteria (Scalbert, 1991). Another study reported condensed tannins to bind the cell walls of ruminal bacteria, thus preventing its growth and protease activity (Jones et al., 1994).

Antimicrobial evaluations confirmed susceptibility of Ayurvedic formulation, Mahamanjishtadi kadha against common skin bacteria and fungi, Staphylococcus aureus, P. aeruginosa, S. Epidermidis and $C$. albicans. The broad spectrum of antimicrobial activity of the herbal ingredients, viz., Manjishtha (Rubia cordifolia Linn), Sariva (Hemidesmus indicus Linn), Nimba (Azadirachta indica A. Juss.), Khadir (Acacia catechu Linn. f.), Haridra (Curcuma longa Linn.), Bibhitaki, (Terminalia bellerica Gaertn.) Roxb.), Haritaki (Terminalia chebula (Gaertn.) Retz.) and Amalaki (Emblica officinalis Gaertn) in composition forms the basis of selection to be incorporated for treating skin infections.

\section{Conclusion}

Mahamanjisthadi kadha was standardized on the basis of the organoleptic, physicochemical, pharmaceutical, microbiological, heavy metals, phytochemical and chromatographic parameters.

Brown colour, bitter and astringent taste, characteristic odour of self generated alcohol, absence of heavy metal, aflatoxins and microbial contamination, $\mathrm{pH}$ of 4.3 , Brix of $30-32 \%$, specific gravity of $1.08 \mathrm{~g} / \mathrm{ml}$, alcohol content of $8.5-9.6 \%$, presence of alkaloids, steroids, triterpenoids, tannins, phenolic compounds, saponins and flavonoids and the marker compounds lupeol, gallic acid and ellagic acid were found to be unique quality features of the Mahamanjisthadi kadha.

The chromatographic data showed presence of all ingredients in the formulation with their unique Rf value. Antimicrobial activity confirmed the potential of formulation Mahamanjisthadi kadha for usage in skin related infections.

This study may serve as standard reference for quality control analysis and checking antimicrobial potential of various Asava, Aristha and kadha formulations. Ethnopharmacologists, microbiologists, and natural-products chemists can use such information of phytochemicals and isolate, characterize more lead phytochemicals which could be developed for the treatment of diseases.

\section{Acknowledgements}

This work was supported by Shree Dhootapapeshwar Limited, Mumbai and MGM School of Biomedical Sciences, MGMIHS, Kamothe, Navi Mumbai.

\section{Conflict of interest}

The authors declare that there are no conflicts of interest in the course of conducting the research. All the authors had final decision regarding the manuscript and decision to submit the findings for publication. 


\section{References}

Alavijeh Parastoo; Alavijeh Parisa and Sharma, D. (2012). A study of antimicrobial activity of few medicinal herbs. Pelagia Research Library Asian Journal of Plant Science and Research, 2(4):496-502

API (2008). The Ayurvedic Pharmacopoeia of India, New Delhi: Ministry of Health and Family Welfare. Department of Ayush; Government of India; Part II (Formulations), Vol II.

API (2008). The Ayurvedic Pharmacopoeia of India. New Delhi: Ministry of Health and Family Welfare. Department of Ayush; Government of India; Part I, Vol VII.

Bhope, S.G.; Nagore, D.H.; Kuber, V.V.; Gupta, P.K. and Patil, M.J. (2011). Design and development of a stable polyherbal formulation based on the results of compatibility studies. Pharmacogn. Res., 3(2):122e9.

Chacko, S.M.; Thambi, P.; Sadanandan, K. and Kimal, A. (2012). Standardization, HPLC analysis and antioxidant study of an ayurvedic formulation dathryarishtam. Int. J. Drug. Discov. Medi. Res., 1:14-18.

Chanda, S.; Kaneria, M.; Baravalia, Y. and Vaghasiya, Y. (2009). Determination of antibacterial and antioxidant potential of some medicinal plants from Saurashtra Region, India. Indian Journal of Pharmaceutical Sciences, 71(4):406.

Clarke, E.G.C. (1975). Isolation and Identification of Drugs, Pharmaceutical Press, London.

Cushnie, T.P.T. and Lamb, A.J. (2005). Antimicrobial activity of flavonoids. International Journal of Antimicrobial Agents, 26(5):343-356. PMID: 16323269 DOI:10.1016/j.ijantimicag.2005.09.002

De, S. (2010). Phytochemical investigation and chromatographic evaluation of the different extracts of tuber of Amorphaphallus paeoniifolius (Araceae). International Journal on Pharmaceutical and Biomedical Research (IJPBR), 1(5):150-157.

Debiyi, O.O. and Sofowora, F. A. (1978). Phytochemical screening of medical plants. Lloyidia, 3:234-246.

Deldar, Y.; Pilehvar-Soltanahmadi, Y.; Dadashpour, M.; Montazer Saheb, S.; Rahmati-Yamchi, M. and Zarghami, N. (2018). An in vitro examination of the antioxidant, cytoprotective and anti-inflammatory properties of chrysin-loaded nano-fibrous mats for potential wound healing applications. Artif. Cells Nanomed. Biotechnol. https://doi.org/ $10.1080 / 21691401.2017 .1337022$

Deshpande, S.W. and Gandhi, N. (2018). Drugs and cosmetics Act, 1940 and Rules 1945, The Medical Devices Rules, 2017. $9^{\text {th }}$ Edition.

Dev, S.K.; Choudhury, P.K.; Srivastava, R. and Sharma, M. (2019). Antimicrobial, anti-inflammatory and wound healing activity of polyherbal formulation. Biomedicine and Pharmacotherapy, 111:555-567.

Di Nubile, M. J. and Lipsky, B. A. (2004). Complicated infections of skin and skin structures: When the infectionis more than skin deep. Journal of Antimicrobial Chemotherapy, 53(S2):ii37-ii50. doi: 10.1093/ $\mathrm{jac} / \mathrm{dkh} 202$.

Feldman, S.; Careccia, R.E.; Barham, K.L. and Hancox, J. (2004). Diagnosis and treatment of acne. Am. Fam. Physician., 69:2123-2130.

Government of India (2016). Gazette notification GSR No. 789(E) dated $12^{\text {th }}$ August 2016 for revising Shelf life of ASU drugs. The Gazette of India, Extraordinary, Part II, Section 3, Subsection (i), New Delhi, $12^{\text {th }}$ August 2016.

Grice, E.A.; Kong, H.H.; Conlan, S.; Deming, C.B.; Davis, J. and Young, A.C. (2009). Topographical and temporal diversity of the human skin microbiome. Science, 324(5931):1190-1192.
Haslam, E. (1996). Natural polyphenols (vegetable tannins) as drugs: Possible modes ofaction. Journal of Natural Products, 59(2):205-215.

ICH (2005). ICH, Q2 (R1), Harmonised tripartite guideline, validation of analytical procedures: Text and methodology, International Conference on Harmonization (ICH), Geneva.

Jones, G.A.; Mc Allister, T.A.; Muir, A.D. and Cheng, K.J. (1994). Effects of sainfoin (Onobrychisviciifolia scop.) condensed tannins on growth and proteolysis by four strains of ruminal bacteria. Appl. Environ. Microbiol., 60:1374-1378.

Kadam, P.V.; Yadav, K.N.; Patel, A.N.; Navsare, V.S.; Narappanawar, N.S. and Patil, M.J. (2012). Comparative account of traditionally fermented biomedicine from ayurveda: Mustakarishta. Int. J. Res. Ayurveda Pharm., 3:429-432.

Kashif, M.; Akhtar, N. and Mustafa, R. (2017). An overview of dermatological and cosmeceutical benefits of Diospyros kaki and its phytoconstituents. Brazilian Journal of Pharmacognocy, 27(5):650-662.

Kathi, C. and Madison (2003). Barrier function ofthe skin: "la raison d'être" of the epidermis. Journal of Investigative Dermatology, 121(2):231-241.

Khandelwal, K.R. (1995). Practical Pharmacognosy. Nirali Prakashan, pp:149-155

Kohen, R. (1999). Skin antioxidants: Their role in aging and in oxidative stress-New approaches for their evaluation. Biomed. and Pharmacother., 53:181-92.

Kokate, C.K.; Purohit, A.P. and Gokhale, S.B. (2009). Pharmacognosy. Nirali Prakashan., pp:6.16-6.17.

Lucchini, J.J.; Corre, J. and Cremieux, A. (1990). Antibacterial activity of phenolic compounds and aromatic alcohols. Res. Microbiol. https:/ /doi.org/10.1016/0923-2508 (90):90075-2

Madison, K.C. (2003). Barrier function of the skin: "la raison d'être" of the epidermis.Journal of Investigative Dermatology, 121(2):231-241.

Malinowska, M.; Miroslaw. B.; Sikora. E.; Ogonowski, J.; Wojtkiewicz, A.M. and Szaleniec, M. et al. (2019). New lupeol esters as active substances in the treatment of skin damage. PLoS ONE 14(3):e0214216. https:/ /doi.org/10.1371/journal. pone.0214216

Marks, J.G. and Miller, J. (2006). Lookingbill and marks' principles of dermatology. Elsevier Inc.; 4th ed. ISBN no. 1416031855.

Marques, D.S. and Marques, M.S. (2018). Medicinal composition having antibiotic, anti-inflammatory, and wound healing activity. United States patent US, 9:980-998.

Maz'uma Abdul Rashid (2018). Antibacterial activity of citrus sinensisand solanum lycopersicumon wound isolated from hospitals in kaduna metropolis kaduna nigeria. International Journal of Biomedical Materials Research, 6(2):40-49.

Mukherjee, P.K. (2002). United States Pharmacopoeia (USP). In: Quality control of herbal drugs. New Delhi: Business Horizons Pharmaceutical Publishers, pp:192e3.

Nduche, M.U.; Egbucha, K.C. and Amakwe, O.C. (2018). Phytochemical screening and antimicrobial activity of four nigerian medicinal plants. International Journal of Research in Pharmacy and Biosciences, 5(2):15-27.

Nipanikar, S.U.; Nagore, D.; Chitlange, S.S. and Buzruk, D. (2017). Evaluation of anti-inflammatory and antimicrobial activity of AHPL/AYTOP/ 0213 cream. AYU, 38(1-2):82-87.

Parekh, J. and Chanda, S. (2007). Antibacterial and phytochemical studies on twelve species of Indian medicinal plants. African Journal of Biomedical Research, 10:175-181. 
Perea, S. and Patterson, T. (2002). Antifungal resistance in pathogenic fungi. Clinical Infectious Diseases, 35(9):1073-1080.

Pilarczyk, R.; Wojcik, J.; Czerniak, P.; Sablik, P.; Pilarczyk, B. and TomzaMarciniak, A. (2013). Concentrations of toxic heavy metals and trace elements in raw milk of simmental and holstein-friesian cows from organic farm. Environ. Monit. Assess, 185(10):8383e92.

Prateek, K.; Geeta, P.; Mahesh, K. and Laxam, R. (2016). Bacteriological study of pyogenic skin infection at tertiary Care Hospital. IOSR Journal of Dental and Medical Sciences, 6(15):114-121.

Proksch, E.; Brandner, J.M. and Jensen, J.M. (2008). The skin: An indispensable barrier. Exp Dermatol., 17(12):1063-1072. doi:10.1111/j.1600$0625.2008 .00786 . x$

Qu, J.; Zhao, X.; Liang, Y.; Zhang, T.; Ma, P.X. and Guo, B. (2018). Antibacterial adhesive injectable hydrogels with rapid self-healing, extensibility and compressibility aswound dressing for joints skin wound healing. Biomaterials. https://doi.org/10.1016/j.biomaterials.2018.08.044.

Rajalakshmy, M.R. and Sindhu, A. (2011). Preliminary phytochemical screening and antioxidant activity of an ayurvedic formulation: Balarishtam. Int. J. Res. Ayurveda Pharm., 2:1645-1647.

Rajani, M. and Kanaki, N.S. (2008). Phytochemical standardization of herbal drugs andpolyherbal formulations. Bioactive molecules and medicinal plants. Berlin, Heidelberg: Springer; pp:349-369.

Raman, N. (2006). Phytochemical Techniques, New Delhi: New Indian Publishing Agencies, pp:19.

Rani; Jamuna; Balakrishnan; Jayshalene; Verma and Rohit (2015). Skin Infections: An association between awareness and quality of life among adults in petaling district, malaysia. European Pharma Congress. J. Pharma Care Health Systems, 2(4):153.

Roopashree, T.S.; Dang, R.; Rani, R.H.S. and Narendra, C. (2008). Antibacterial activity of antipsoriatic herbs: Cassia tora, momordicacharantia and calendula officinalis. International Journal Applied Research in Natural Products, 1(3):20-28.

Santosh, M.K.; Shaila, D. and Rao, I.S. (2003). Standardization of selected asavas and arishtas. Asian J. Chem., 15:884-890.

Scalbert, A. (1991). Antimicrobial properties of tannins. Phytochemistry, 30:3875-3883.

Shrivastava, S. (1998). Sharangadhar samhita of pandit sharangdhara acharya, Madhyam Khanda, 2:139-144.

Siddiqui Hakim, M.A. (1995). Format for the pharmacopoeial analytical standards of compound formulation, workshop on standardization of Unani Drugs (Appendix). New Delhi: Central Council for Research in Unani Medicine (CCRUM).

Singh, H.; Mishra, S. K. and Pande, M. (2010). Standardization of Arjunarishtaformulation by TLC method. International Journal of Pharmaceutical Sciences Review and Research, 2(1) May-June 2010; Article 007.
Singh, S; J.S. Tripathi and N.P. Rai (2014). An overview of Ayurvedic \& contemporary approaches to Psychodermatology. The Journal of Phytopharmacology, 3(4):286-299.

Sofowora (1993). Phytochemical screening of medicinal plants and traditional medicine in africa, Spectrum Books Ltd, Ibadan, Nigeria.

Tabassum, N. and Hamdani, M. (2014). Plants used to treat skin diseases. Pharmacogn. Rev., 8(15):52-60.

Taid, T.C.; Rajkhowa, R.C. and Kalita, J.C. (2014). A study on the medicinal plants used by the local traditional healers of Dhemaji district, Assam, India for curing reproductive health related disorders. Pelagia Research Library, Advances in Applied Science Research, 5(1):296-301.

Tiwari, P. and Patel, R.K. (2011). Total phenolics and flavonoids and antioxidant potential of draksharishta prepared by traditional and modern methods. Pharmacology, 3:1072-1082.

Trease, G. E. and Evans, W. C. (1989). Textbook of Pharmacognosy, Balliese, Tindall and Co Publishers, London, UK, 12:343-383.

Tümen; Akkol E.K.; Taştan, H.; SüntarI and Kurtca, M. (2018). Research on the antioxidant, wound healing, and anti-inflammatory activities and the phytochemical composition of maritime pine (PinuspinasterAit). J. Ethnopharmacol., https://doi.org/10.1016/j.jep.2017.09.009.

Vaidya, A.D.B. and Devasagayam, T.P.A. (2007). Current status of herbal drugs in India: An overview. J. Clin. Biochem., 41(1):1e11.

Varma, S.R.; Sivaprakasam, T.O.; Mishra, A.; Kumar, L.M.S.; Prakash, N.S. and Prabhu, S. (2016). Protective effects of triphala on dermal fibroblasts and human keratinocytes. PLoS ONE 11(1):e0145921. doi: 10.1371/ journal.pone.0145921

WHO (1992). Quality control methods for medicinal plant materials. World Health Organisation, Geneva, Switzerland.

WHO (1998). Quality control methods for medicinal plant materials. World Health Organization, Geneva, Switzerland.

WHO (2018). Mycotoxins. World Health Organization (WHO) Newsletter $9^{\text {th }}$ May 2018. https://www.who.int/news-room/fact-sheets/detail/ mycotoxins

Zhao, W.; Qiu, M.Y.; Ma, C.X.; Gong, P.H.; Liu, Y.T.; Yan, M.M.; Shao, S. and Zhao, D.Q. (2018). Promote healing and anti-inflammatory and antibacterial activities of Jinjianling cream. J. Pharmacol. Thera. Res.

Zinn, C.; Westh, H. and Rosdahl, V. (2004). An international nulticenter study of antimicrobial resistance and typing of hospital staphylococcus aureus isolates from 21 Laboratories in 19 Countries or States. Microbial Drug Resistance, 10(2):160-168.

Citation: Kapil Thakur, P. Mini Mol, Madhuree Gawhankar, Himanshu Gupta, Priyanka Patil, Shabina Salmani and Mansee Thakur (2020). Physicochemical characterization and antimicrobial properties of Mahamanjishthadi kadha: An Ayurvedic formulation. Ann. Phytomed., 9(1):78-90. http://dx.doi.org/10.21276/ap.2020.9.1.9 